\title{
FAKTOR-FAKTOR YANG MEMPENGARUHI NILAI PERUSAHAAN
}

\author{
Sutandi ${ }^{(1)}$
}

Universitas Buddhi Dharma

Sutandi023@gmail.com

\begin{abstract}
The purpose of this study was to determine the factors that influence the value of the company in banking companies listed on the Indonesia Stock Exchange (IDX). The research period used was 6 years, namely the period 2013-2018. The population of this study includes all banking sectors listed on the Indonesia Stock Exchange (IDX) in the period 2013-2018. The sampling technique uses purposive sampling technique. Based on predetermined criteria obtained a sample of 27 companies. The type of data used is secondary data obtained from the Indonesia Stock Exchange (IDX) website. In this study the data analysis method used is multiple linear regression analysis. The results showed that partially Investment Decision, Dividend Policy, Capital Structure, Leverage, Profitability, and Company Size significantly influence Company Value, while simultaneously Investment Decisions, Dividend Policy, Capital Structure, Leverage, Profitability, and Company Size also significantly influence on Company Value.
\end{abstract}

Keywords: Investment Decisions, Dividend Policy, Capital Structure, Leverage, Profitability, Company Size, Company Value. 


\section{PENDAHULUAN}

Perusahaan Perbankan adalah salah satu lembaga keuangan yang kegiatan utamanya adalah menghimpun dana dari masyarakat dalam bentuk simpanan, giro maupun deposito serta menyalurkan dana kepada masyarakat dalam bentuk kredit, dan bentuk-bentuk produk jasa keuangan lainnya. Saat ini perkembangan dan kemajuan di sektor perbankan sangatlah pesat, hal tersebut ditandai dengan banyaknya perusahaan perbankan yang beroperasi di Indonesia (Ananto dan Sri Hermuningsih, 2018).

Keputusan investasi merupakan faktor penting dalam fungsi keuangan perusahaan, karena untuk mencapai tujuan perusahaan dapat dicapai melalui kegiatan investasi perusahaan. Investasi modal merupakan salah satu aspek utama dalam keputusan investasi selain penentuan komposisi aktiva (Nuryani, 2018).

Kebijakan dividen adalah kebijakan yang berkaitan dengan keputusan untuk membagi laba yang diperoleh kepada pemegang saham sebagai dividen atau akan menahan dalam bentuk laba ditahan untuk digunakan sebagai pembiayaan investasi pada masa yang akan datang (Ananto dan Sri Hermuningsih, 2018). Kebijakan dividen adalah untuk menentukan berapa banyak keuntungan yang akan diperoleh pemegang saham. Keuntungan yang akan diperoleh pemegang saham ini akan menentukan kesejahteraan para pemegang saham yang merupakan tujuan utama perusahaan. Pembayaran dividen yang semakin besar sebagai indikator nilai perusahaan (Kharis Raharjo, 2016).

Struktur modal merupakan kombinasi spesifik antara utang dan modal sendiri yang digunakan untuk memaksimalkan nilai perusahaan dengan memilih biaya modal yang rendah (Nony Kezia M. dan Dewi Astuti, 2015). Menurut Meythi (2012), dalam menentukan struktur modal, perusahaan harus mempertimbangkan perbandingan utang dengan modal sendiri karena akan berpengaruh terhadap nilai perusahaan. Perusahaan yang menggunakan utang dalam pengoperasiannya akan mendapat penghematan pajak, karena pajak dihitung dari laba operasi setelah dikurangi utang bunga, sehingga laba bersih yang menjadi hak pemegang saham akan menjadi lebih besar dibandingkan dengan perusahaan yang tidak menggunakan utang.

Leverage merupakan suatu ukuran seberapa besar aset yang dimiliki perusahaan dibiayai oleh utang. Leverage menunjukkan penggunaan utang untuk membiayai investasi (Ida Ayu \& Putu Ery Setiawan, 2016). Perusahaan yang memiliki tingkat leverage yang tinggi dapat menunjukkan bahwa perusahaan tersebut sedang mengalami kesulitan keuangan (Putri Intan, et al, 2016).

Profitabilitas adalah kemampuan perusahaan memperoleh laba. Laba diperoleh perusahaan berasal dari penjualan dan keputusan investasi yang dilakukan perusahaan. Profitabilitas yang tinggi menunjukkan prospek perusahaan yang bagus sehingga investor akan merespon positif dan harga saham akan meningkat (Fama dan French, 1998 dalam Mei Yuniati, 2016). Profitabilitas diartikan sebagai kemampuan perusahaan dalam menghasilkan keuntungan dan mengukur tingkat efisiensi operasional dan efisiensi dalam menggunakan harta yang dimilikinya (Chen, 2004 dalam Isabella Permata, 2017).

Ukuran perusahaan dilihat dari total aset yang dimiliki oleh perusahaan yang dapat dipergunakan untuk kegiatan operasional perusahaan. Total aset yang besar memudahkan perusahaan dalam 
masalah pendanaan kebutuhan perusahaan. Jika dilihat dari sisi manajemen, kemudahan yang dimilikinya dalam mengendalikan perusahaan akan meningkatkan nilai perusahaan. Ukuran perusahaan juga merupakan salah satu faktor yang perlu dipertimbangkan oleh calon investor (Heven Manoppo \& Fitty Valdi Arie, 2016).

Menurut hasil penelitian yang dilakukan Ardianti Fajriana (2016), setelah menguji pengaruh corporate social responsibility, keputusan investasi, dan struktur modal terhadap nilai perusahaan, bahwa hasil penelitian secara parisal: keputusan investasi (PER) berpengaruh signifikan terhadap nilai perusahaan (PBV), dan struktur modal (DER) tidak berpengaruh signifikan terhadap nilai perusahaan (PBV), serta secara simultan: keputusan investasi (PER) \& struktur modal (DER) secara simultan berpengaruh signifikan terhadap nilai perusahaan (PBV). Selanjutnya menurut Rohmat Adi Saputro (2018), setelah menguji perusahaan manufaktur yang terdaftar di Bursa Efek Indonesia (BEI) pada periode tahun 2013-2015, ditemukan bahwa secara parisal: variabel leverage (DAR) tidak berpengaruh secara signifikan terhadap nilai perusahaan (PBV), sedangkan variabel profitabilitas (ROE), ukuran perusahaan (Size), struktur modal (DER), \& kebijakan dividen (DPR) berpengaruh signifikan terhadap nilai perusahaan (PBV), serta secara simultan: variabel leverage (DAR), profitabilitas (ROE), ukuran perusahaan (Size), struktur modal (DER), \& kebijakan dividen (DPR) secara simultan berpengaruh signifikan terhadap nilai perusahaan (PBV).

\section{KAJIAN LITERATURE DAN PENGEMBANGAN HIPOTESIS}

\section{Signalling Theory}

Menurut Brigham dan Houston dalam Irma Desmi Awulle1 (2018), isyarat atau signal adalah suatu tindakan yang diambil manajemen perusahaan yang memberi petunjuk bagi investor tentang bagaimana manajemen memandang prospek perusahaan. Teori signaling menyatakan bahwa perusahaan yang berkualitas baik dengan sengaja akan memberikan signal pada pasar dengan demikian pasar diharapkan dapat membedakan perusahaan yang berkualitas baik dan buruk. Menurut Spence dalam Aniela Nurminda (2017), mengemukakan bahwa isyarat memberikan suatu sinyal, pihak pengirim (pemilik informasi) berusaha memberikan potongan informasi relevan yang dapat dimanfaatkan oleh pihak penerima. Pihak penerima kemudian akan menyesuaikan perilakunya sesuai dengan pemahamannya terhadap sinyal tersebut.

\section{Pengaruh secara parsial Keputusan Investasi terhadap Nilai Perusahaan.}

Hasil pengujian secara parsial Keputusan Investasi terhadap Nilai Perusahaan menunjukkan nilai signifikan sebesar $0,012<0,05$. Maka dapat disimpulkan bahwa secara parsial Keputusan Investasi berpengaruh signifikan terhadap Nilai Perusahaan. Hasil penelitian ini menunjukkan bahwa semakin tinggi tingkat keputusan investasi yang ditetapkan perusahaan maka akan menghasilkan kesempatan yang tinggi pula untuk mendapatkan keuntungan yang besar. Dengan perusahaan yang memiliki keputusan investasi yang tinggi maka mampu untuk memengaruhi pemahaman investor untuk tertarik dalam melakukan investasi kepada perusahaan tersebut sehingga mampu meningkatkan permintaan terhadap saham pada perusahaan. 


\section{Pengaruh secara parsial Kebijakan Dividen terhadap Nilai Perusahaan.}

Hasil pengujian secara parsial Kebijakan Dividen terhadap Nilai Perusahaan menunjukkan nilai signifikan sebesar $0,000<0,05$. Maka dapat disimpulkan bahwa secara parsial Kebijakan Dividen berpengaruh signifikan terhadap Nilai Perusahaan. Hasil penelitian ini menunjukkan bahwa semakin besar dividen yang dibagikan oleh perusahaan kepada pemegang saham, maka kinerja perusahaan akan dianggap baik dan menjadi sinyal bahwa perusahaan yang dianggap memiliki prospek yang baik dan akan dianggap menguntungkan, sehingga penilaian terhadap perusahaan yang baik yang dapat dilihat dari tingkat harga saham perusahaan. Maka dalam hal ini kebijakan dividen berpengaruh terhadap nilai perusahaan karena dengan adanya pembagian dividen yang tinggi menunjukkan bahwa perusahaan mampu memenuhi kebutuhan perusahaan dan mengembalikan modal kepada investor.

\section{Pengaruh secara parsial Struktur Modal terhadap Nilai Perusahaan.}

Hasil pengujian secara parsial Struktur Modal terhadap Nilai Perusahaan menunjukkan nilai signifikan sebesar 0,003 $<0,05$. Maka dapat disimpulkan bahwa secara parsial Struktur Modal berpengaruh signifikan terhadap Nilai Perusahaan. Hasil penelitian ini menunjukkan bahwa apabila terjadi pertambahan utang, akan menyebabkan meningkatnya nilai perusahaan. Oleh karena itu, tingginya nilai struktur modal akan mempengaruhi tingginya nilai perusahaan. Dengan menetapkan struktur modal secara tepat, pertambahan utang akan menyebabkan meningkatnya produktivitas perusahaan yang nantinya perusahaan dalam beroperasi akan lebih berjalan secara optimal tanpa kekurangan dana. Akibat dari suatu pendanaan tersebut, perusahaan akan jauh lebih memiliki cukup modal untuk melakukan ekspansi, sehingga perusahaan akan semakin berkembang dan berjalan lebih maju. Nantinya secara tidak langsung dapat menambah pendapatan perusahaan yang pada akhirnya akan berdampak pada kemakmuran pemegang saham. Semakin besar Debt to Equity Ratio (DER), menunjukkan komposisi total utang semakin besar dibanding dengan total modal sendiri sehingga meningkatkan tingkat risiko yang diterima investor dan menurunnya harga saham.

\section{Pengaruh secara parsial Leverage terhadap Nilai Perusahaan.}

Hasil pengujian secara parsial Leverage terhadap Nilai Perusahaan menunjukkan nilai signifikan sebesar 0,002 $<0,05$. Maka dapat disimpulkan bahwa secara parsial Leverage berpengaruh signifikan terhadap Nilai Perusahaan. Hasil penelitian ini menunjukkan bahwa semakin tinggi rasio leverage berarti semakin tinggi utang perusahaan. Hal ini akan menyebabkan terjadinya penurunan nilai perusahaan di mata investor sehingga mengakibatkan sikap keraguan untuk menanamkan dananya pada perusahaan.

\section{Pengaruh secara parsial Profitabilitas terhadap Nilai Perusahaan.}

Hasil pengujian secara parsial Profitabilitas terhadap Nilai Perusahaan menunjukkan nilai signifikan sebesar 0,009 $<0,05$. Maka dapat disimpulkan bahwa secara parsial Profitabilitas berpengaruh signifikan terhadap Nilai Perusahaan. Hasil penelitian ini menunjukkan bahwa semakin tinggi laba yang didapatkan oleh perusahaan menandakan semakin besar pula return dari pada modal investor, yang mana hal tersebut tentu akan lebih membuat investor tertarik untuk menanamkan modalnya di perusahaan 
tersebut. Dengan semakin banyaknya permintaan investasi maka akan semakin tinggi pula harga saham perusahaan tersebut. Jika harga saham suatu perusahaan naik maka hal itu menandakkan bahwa nilai perusahaan tersebut juga naik. Dengan kata lain perusahaan yang memiliki profitabilitas yang cukup tinggi akan mendapatkan dana yang cukup, karena prospek perusahaan yang bagus sehingga memicu permintaan saham oleh investor. Respon positif dari investor tersebut akan meningkatkan harga saham dalam menghasilkan laba perusahaan dan selanjutnya akan meningkatkan nilai perusahaan. Sehingga perusahaan dapat meningkatkan kinerjanya yang mengakibatkan meningkatnya nilai perusahaan dalam menghasilkan laba. Perusahaan yang dapat menghasilkan laba disetiap tahunnya akan membuat ketertarikan investor. Investor akan mempercayai perusahaan yang mampu menghasilkan profit yang besar karena return yang diperoleh juga besar, sehingga hal tersebut dapat menjadi sinyal positif untuk investor. Hal ini sesuai dengan konsep dari signaling theory yang mengatakan bahwa profitabilitas suatu perusahaan akan menjadi sinyal dari manajemen yang menggambarkan prospek perusahaan. Dan hal tersebut akan digunakan manajer perusahaan untuk memperoleh modal dalam bentuk saham. Oleh karena itu profitabilitas berpengaruh terhadap nilai perusahaan karena respon positif dari investor tersebut akan meningkatkan harga saham dan selanjutnya akan meningkatkan nilai perusahaan.

\section{Pengaruh secara parsial Ukuran Perusahaan terhadap Nilai Perusahaan.}

Hasil pengujian secara parsial Ukuran Perusahaan terhadap Nilai Perusahaan menunjukkan nilai signifikan sebesar 0,015 $<0,05$. Maka dapat disimpulkan bahwa secara parsial Ukuran Perusahaan berpengaruh signifikan terhadap Nilai Perusahaan. Hasil penelitian ini menunjukkan bahwa ukuran perusahaan yang besar menunjukkan jika perusahaan tersebut memiliki komitmen yang tinggi untuk terus berkembang dan maju. Dengan demikian pasar akan bersedia membayar lebih mahal untuk mendapatkan sahamnya karena kepercayaanya akan pengembalian yang diharapkan. Perusahaan yang berukuran besar dapat dengan mudah mengakses ke pasar modal. Kemudahan dalam mengakses ke pasar modal berarti perusahaan memiliki fleksibilitas dan kemampuan untuk mendapatkan dana, yang nantinya dana tersebut dapat dengan mudah dimunculkan kembali dalam jumlah yang lebih besar. Adanya kemudahan tersebut ditangkap oleh investor sebagai sinyal posistif sehingga meningkatkan nilai perusahaan. sehingga semakin besar ukuran perusahaan maka nilai perusahaan akan semakin baik.

\section{Pengaruh Keputusan Investasi, Kebijakan Dividen, Struktur Modal, Leverage, Profitabilitas, dan Ukuran Perusahaan secara simultan terhadap Nilai Perusahaan.}

Hasil pengujian secara simultan Keputusan Investasi, Kebijakan Dividen, Struktur Modal, Leverage, Profitabilitas, dan Ukuran Perusahaan terhadap Nilai Perusahaan menunjukkan nilai signifikan sebesar $0,000<0,05$, serta hasil analisis regresi linier berganda yang masing-masing variabel independen bernilai positif, antara lain Keputusan Investasi sebesar 0,621, Kebijakan Dividen sebesar 1,302, Struktur Modal sebesar 0,711, Leverage sebesar 4,268, Profitabilitas sebesar 2,281, dan Ukuran Perusahaan sebesar 0,121. Maka dapat disimpulkan bahwa Keputusan Investasi, Kebijakan Dividen, Struktur Modal, Leverage, Profitabilitas, dan Ukuran Perusahaan secara simultan berpengaruh 
signifikan terhadap Nilai Perusahaan. Hal ini menunjukkan bahwa meningkatkan. Keputusan Investasi, Kebijakan Dividen, Struktur Modal, Leverage, Profitabilitas, dan Ukuran Perusahaan. Nilai Perusahaan didasari oleh adanya Signalling Theory yang menyatakan bahwa perusahaan yang berkualitas baik dengan sengaja akan memberikan signal pada pasar dengan demikian pasar diharapkan dapat membedakan perusahaan yang berkualitas baik dan buruk. Investor selalu membutuhkan informasi yang simetris sebagai pemantauan dalam menanamkan dana pada suatu perusahaan, jadi sangat penting bagi perusahaan untuk memberikan informasi setiap akun rekening pada laporan keuangan dimana merupakan sinyal untuk diinformasikan kepada investor maupun calon investor. Hasil penelitian ini sesuai dengan penelitian yang dilakukan oleh Dewi Nindy Lestari (2018).

\section{METODE PENELITIAN Nilai Perusahaan}

Nilai perusahaan adalah kinerja perusahaan yang dicerminkan oleh harga saham yang dibentuk oleh permintaan dan penawaran pasar modal yang merefleksikan penilaian masyarakat terhadap kinerja perusahaan (Harmono, 2015). Menurut Husnan (2017) menyatakan bahwa nilai perusahaan adalah nilai yang dibutuhkan investor untuk mengambil keputusan investasi yang tercermin dari harga pasar perusahaan.

\section{Keputusan Investasi}

Menurut Sutrisno (2014) pengertian keputusan investasi adalah keputusan yang sering disebut capital budgeting, yaitu keseluruhan proses perencanaan dan pengambilan keputusan mengenai pengeluaran dan yang jangka waktu kembalinya dana tersebut melebihi satu tahun atau berjangka panjang. Keputusan investasi merupakan keputusan yang menyangkut pengalokasian dana yang berasal dari dalam maupun dana yang berasal dari luar perusahaan pada berbagai bentuk investasi (Purnamasari dkk, dalam Fenandar, 2016).

\section{Kebijakan Dividen}

Kebijakan dividen sebuah perusahaan memiliki dampak penting bagi banyak pihak yang terlibat di masyarakat (Suharli, 2014). Kebijakan dividen adalah keputusan apakah laba yang diperoleh perusahaan akan dibagikan kepada pemegang saham sebagai dividen atau akan ditahan dalam bentuk laba ditahan guna pembiayaan investasi dimasa datang (Sartono, 2016), Sedangkan menurut Riyanto (2016) kebijakan dividen adalah kebijakan yang bersangkutan dengan penentuan pembagian pendapatan antara pengguna pendapatan untuk dibayarkan kepada para pemegang saham sebagai dividen atau untuk digunakan dalam perusahaan, yang berarti pendapatan tersebut harus ditanam di dalam perusahaan.

\section{Struktur Modal}

Menurut Sartono (2016) struktur modal merupakan perimbangan jumlah utang jangka pendek yang bersifat permanen, utang jangka panjang, saham preferen dan saham biasa. Sedangkan menurut Irham Fahmi (2015), struktur modal merupakan gambaran dari bentuk proporsi finansial perusahaan yang menjadi pembiayaan suatu perusahaan. Struktur modal adalah pembelanjaan permanen dimana mencerminkan perimbangan antara hutang jangka panjang dengan modal sendiri (Wibowo, 2017).

\section{Competitive Jurnal Akuntansi dan Keuangan, Vol. 4 (No.2),E-ISSN 2549-79IX}




\section{Leverage}

Leverage merupakan rasio antara total hutang dengan total aset yang dinyatakan dalam persentase (Martono dan Harjito, 2015). Leverage mengacu pada penggunaan aset dan sumber dana oleh perusahaan dimana dalam penggunaan aset atau dana tersebut perusahaan harus mengeluarkan beban tetap. Perubahan leverage menghasilkan perubahan dalam tingkat pengembalian dan risiko (Sunjdaja dan Berlian, 2016).

\section{Profitabilitas}

Profitabilitas adalah rasio yang menggambarkan kinerja fundamental perusahaan ditinjau dari tingkat efesiensi dan efektivitas operasi perusahaan dalam memperoleh laba (Harmono, 2016). Menurut Syafri (2017) profitabilitas merupakan rasio yang menggambarkan kemampuan perusahaan dalam mendapatkan laba melalui semua kemampuan perusahaan dalam mendapatkan laba melalui semua kemampuan dan sumber daya yang ada.

\section{Ukuran Perusahaan}

Menurut Machfoedz dalam Suwito dan Herawati (2015), menyatakan bahwa ukuran perusahaan merupakan suatu skala yang dapat mengelompokkan perusahaan menjadi perusahaan besar dan kecil menurut berbagai cara seperti contoh, ukuran perusahaan bisa kita lihat melalui total aset perusahaan yang dimiliki, nilai pasar saham, rata-rata tingkat penjualan, dan jumlah penjualan.

\section{METODE ANALISIS DATA}

Teknik analisis data yang digunakan dalam penelitian yaitu menggunakan:

Statistik deskriptif memberikan gambaran atau deskripsi suatu data yang dilihat dari nilai rata-rata (mean), standar deviasi, varian, maksimum, minimum, sum, range, kurtosis dan skewness/ kemencengan distribusi (Imam Ghozali, 2018:19).

Uji Asumsi Klasik dalam analisis regresi tersebut ada beberapa asumsi yang harus dipenuhi agar persamaan regresi tersebut valid untuk digunakan dalam penelitian. Asumsi-asumsi tersebut disebut dengan asumsi klasik. Uji Normalitas Data, menurut Imam Ghozali (2018:161) uji normalitas bertujuan untuk menguji apakah dalam model regresi, variabel penganggu atau residual memiliki distribusi normal, $\mathbf{U j i}$ Multikolonieritas bertujuan untuk menguji apakah model regresi ditemukan adanya korelasi antar variabel bebas (independen). Model regresi yang baik seharusnya tidak terjadi korelasi di antara variabel independen, Untuk mendeteksi ada atau tidaknya multikolonieritas didalam model regresi adalah dengan kriteria sebagai berikut: tidak ada variabel yang nilai Tolerance $\leq 0,10$ serta tidak ada variabel yang nilai VIF $\geq 10$, Uji Autokorelasi bertujuan untuk menguji apakah dalam model regresi linear ada korelasi antara kesalahan pengganggu pada periode $t$ dengan kesalahan pengganggu pada periode $\mathrm{t}-1$ atau periode sebelumnya untuk mendeteksi ada atau tidaknya autokorelasi dengan uji Durbin-Watson (DW test) hanya digunakan untuk autokorelasi tingkat satu (first order autocorrelation) dan mensyaratkan adanya intercept (konstanta) dalam model regresi dan tidak ada variabel lag diantara variabel independen, $\mathbf{U j i}$ Heteroskedastisitas bertujuan untuk menguji apakah dalam model regresi terjadi ketidaksamaan variance dari residual satu pengamatan ke pengamatan yang lain, menurut Imam Ghozali (2018:142) Untuk mendeteksi ada atau tidaknya heteroskedastisitas dengan melakukan Uji Glejser. Uji Glejser mengusulkan untuk 
meregres nilai absolut residual terhadap nilai varaibel independen.

\section{Pengujian Hipotesis, Uji Koefisien} Determinasi $\left(\mathbf{R}^{\mathbf{2}}\right)$ pada intinya mengukur seberapajauh kemampuan dalam menerangkan variasi variabel dependen. Nilai koefisien determinasi adalah antara 0 dan 1. Nilai $\mathrm{R}^{2}$ yang kecil berarti kemampuan variabel-variabel independen dalam menjelaskan variasi variabel dependen amat terbatas. Nilai yang mendekati 1 berarti variabel-variabel independen hampir memberikan semua informasi yang dibutuhkan untuk memprediksi variasi variabel dependen, menurut Imam Ghozali (2018:98) Uji Statistik $t$ pada dasarnya menunjukkan seberapa jauh pengaruh satu variabel penjelas/ independen secara individual dalam menerangkan variasi variabel dependen, menurut Imam Ghozali (2018:98) Uji Statistik $\mathbf{F}$ menguji joint hipotesia bahwa b1, b2, b3, b4, dan b5 secara bersama-sama. Analisis Regresi Linier Berganda Hasil analisis regresi adalah berupa koefisien untuk variabel independen. Koefisien ini diperoleh dengan cara memprediksi nilai variabel dependen dengan suatu persamaan. Dalam analisis regresi selain mengukur kekuatan hubungan antara dua variabel atau lebih, juga menunjukkan arah hubungan antara variabel dependen dengan variabel independen. Penelitian ini menggunakan analisis regresi linier berganda digunakan untuk mengetahui ada tidaknya pengaruh variabel independen (X1), variabel independen (X2) terhadap variabel dependen (Y). Hubungan tersebut diukur dengan model persamaan sebagai berikut (Imam Ghozali, 2018:101).

\section{HASIL DAN PEMBAHASAN}

\section{Uji Normalitas Data}

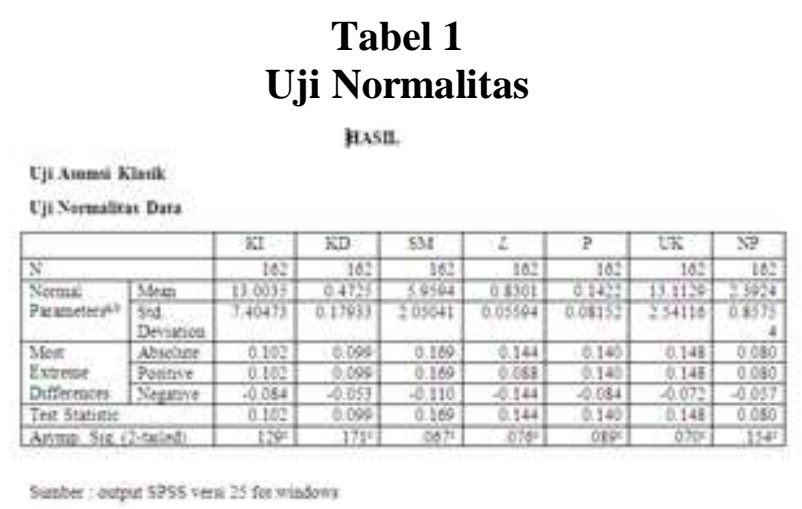

Berdasarkan tabel diatas nilai Asymp. Sig. (2-tailed) lebih dari 0,05. Hal ini dapat disimpulkan bahwa data sampel berdistribusi normal.

\section{Uji Multikolonieritas}

Tabel 2

\section{Uji Multikolonieritas}

\begin{tabular}{|l|l|c|c|}
\hline \multirow{2}{*}{ Model } & \multicolumn{2}{c|}{ Collinearity Statistics } \\
\cline { 2 - 4 } & \multicolumn{2}{|c|}{ Tolerance } & VIF \\
\hline \multirow{3}{*}{1} & (Constant) & & \\
\cline { 2 - 4 } & KI & 0.982 & 1.018 \\
\cline { 2 - 4 } & KD & 0.919 & 1.089 \\
\cline { 2 - 4 } & SM & 0.541 & 1.849 \\
\cline { 2 - 4 } & I & 0.646 & 1.548 \\
\cline { 2 - 4 } & P & 0.774 & 1.291 \\
\cline { 2 - 4 } & UP & 0.864 & 1.157 \\
\hline
\end{tabular}

Dari hasil uji multikolonieritas pada tabel diatas hasil perhitungan tidak ada satu variabel independen yang memiliki nilai Tolerence menunjukkan kurang dari 0,10 dan hasil perhitungan Variance Inflation Factor (VIF) juga menunjukkan hal yang sama tidak ada satu variabel independen yang memiliki nilai VIF lebih dari 10. Sehingga dapat disimpulkan bahwa tidak ada multikolonieritas antar variabel independen dalam model regresi tersebut. 


\section{Uji Autokorelasi}

Tabel 3

Uji Autokorelasi

\begin{tabular}{|c|c|c|c|c|c|}
\hline Nov & $R$ & $\begin{array}{c}R \\
\text { Square }\end{array}$ & $\begin{array}{l}\text { Adjusted } \\
\text { RSquare }\end{array}$ & $\begin{array}{l}\text { Srd Eroror of } \\
\text { the Estimate }\end{array}$ & $\begin{array}{l}\text { Dution- } \\
\text { Watson }\end{array}$ \\
\hline & 8528 & 0.724 & 0712 & 0.14952 & \\
\hline
\end{tabular}

Dari hasil hasil pengolahan data diatas diperoleh nilai $\mathrm{du}<\mathrm{d}<4-$ du yaitu $1,820<$ $1,988<2,179$, sehingga Tidak ada autokorelasi positif atau negatif dan keputusan tidak ditolak. Jadi dapat disimpulkan bahwa dalam model regresi ini tidak terjadi autokorelasi.

\section{Uji Heteroskedastisitas}

Dari hasil uji heteroskedasitas dari tabel diatas merupakan hasil uji heteroskedastisitas dengan uji glejser, dimana hasil tersebut bahwa nilai probabilitas signifikan kedua variabel tersebut lebih dari 0,05, sehingga dapat dikatakan bahwa model regresi linier pada penelitian ini tidak terjadi heteroskedastisitas

\section{Tabel 4}

\section{Uji Heteroskedastisitas}

\begin{tabular}{|c|c|c|c|c|c|c|}
\hline \multirow{2}{*}{\multicolumn{2}{|c|}{ Model }} & \multicolumn{2}{|c|}{$\begin{array}{l}\text { Unstandardized } \\
\text { Coefficients }\end{array}$} & \multirow{2}{*}{\begin{tabular}{|c}
$\begin{array}{c}\text { Standardized } \\
\text { Coefficients }\end{array}$ \\
Beta
\end{tabular}} & \multirow[b]{2}{*}{$\mathrm{t}$} & \multirow[b]{2}{*}{ Sig. } \\
\hline & & B & Std. Error & & & \\
\hline \multirow[t]{7}{*}{1} & (Constant) & -0.797 & 1.110 & & 0.717 & 0.474 \\
\hline & KI & 0.021 & 0.008 & 0.184 & 2.545 & 0.712 \\
\hline & $\mathrm{KD}$ & 1,302 & 0.358 & 0.272 & 3.642 & 0.560 \\
\hline & SM & 0.111 & 0.041 & 0.027 & 0.276 & 0.783 \\
\hline & I & 4.268 & 1.367 & 0.278 & 3.122 & 0.082 \\
\hline & P & 2281 & 0.857 & 0.217 & 2.662 & 0.189 \\
\hline & UP & 0.121 & 0.026 & 0.062 & 0.800 & 0.425 \\
\hline
\end{tabular}

\section{Pengujian Hipotesis}

\section{Analisis Regresi Linier Berganda}

Berikut adalah hasil analisis regresi linier berganda:

Tabel 4

\section{Regresi Linier Berganda}

\begin{tabular}{|c|c|c|c|c|}
\hline \multirow{2}{*}{\multicolumn{2}{|c|}{ Model }} & \multicolumn{2}{|c|}{ Unstandardized Coefficients } & \multirow{2}{*}{$\begin{array}{l}\begin{array}{l}\text { Standardized } \\
\text { Coefficients }\end{array} \\
\text { Beta }\end{array}$} \\
\hline & & B & Std. Error & \\
\hline \multirow[t]{7}{*}{1} & (Coustant) & -0.797 & 1.110 & \\
\hline & $\mathrm{KI}$ & 0.621 & 0.008 & 0.184 \\
\hline & $\mathrm{KD}$ & 1302 & 0358 & 0.272 \\
\hline & SM & 0,711 & 0.041 & 0.027 \\
\hline & L & 4268 & 1367 & 0.278 \\
\hline & $\mathrm{P}$ & 2.281 & 0.857 & 0.217 \\
\hline & UP & 0121 & 0.026 & 0.062 \\
\hline
\end{tabular}

Dalam analisis regresi selain mengukur kekuatan hubungan antara dua variabel atau lebih, juga menunjukkan arah hubungan antara variabel dependen dengan variabel independen. Penelitian ini menggunakan analisis regresi linier berganda digunakan untuk mengetahui ada tidaknya pengaruh (X1), (X2), (X3), (X4), (X5), (X6) terhadap (Y).

\section{Uji Koefisien Determinasi $\left(\mathbf{R}^{2}\right)$}

pada intinya mengukur seberapa jauh kemampuan dalam menerangkan variasi variabel dependen. Nilai koefisien determinasi adalah antara 0 dan 1. Nilai R2 yang kecil berarti kemampuan variabelvariabel independen dalam menjelaskan variasi variabel dependen sangat terbatas. Nilai yang mendekati 1 berarti variabelvariabel independen hampir memberikan semua informasi yang dibutuhkan untuk memprediksi variasi variabel dependen.

Tabel 6

Koefisien Determinasi

\begin{tabular}{|l|c|r|r|r|}
\hline Model & $\mathrm{R}$ & $\begin{array}{c}\mathrm{R} \\
\text { Square }\end{array}$ & $\begin{array}{c}\text { Adjusted } \\
\text { R Square }\end{array}$ & $\begin{array}{c}\text { Std. Error of } \\
\text { the Estimate }\end{array}$ \\
\hline 1 & $.852^{\mathrm{a}}$ & 0.724 & 0.712 & 0.14952 \\
\hline
\end{tabular}


Pada tabel diatas nilai Adjusted $\mathrm{R}$ Square sebesar 0,71, hal ini berarti $71 \%$ variasi nilai perusahaan dapat dijelaskan oleh variasi dari keenam variabel independen yaitu keputusan investasi, kebijakan dividen, struktur modal, leverage, profitabilitas dan ukuran perusahaan. Sedangkan sisanya (100\% - $71 \%=29 \%$ ) dijelaskan oleh sebab-sebab yang lain diluar model.

Uji Signifikansi Parameter Individual (Uji Statistik t)

Tabel 7

Uji $\mathbf{t}$

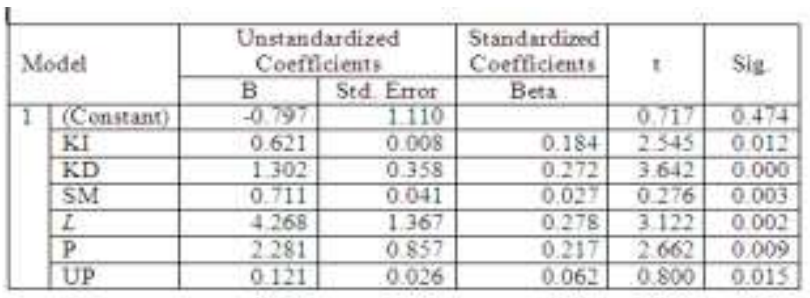

1. Nilai signifikan sebesar $0,012<0,05$. Sehingga dapat disimpulkan bahwa secara parsial Keputusan Investasi berpengaruh signifikan terhadap Nilai Perusahaan.

2. Nilai signifikan sebesar $0,000<0,05$. Sehingga dapat disimpulkan bahwa secara parsial Kebijakan Dividen berpengaruh signifikan terhadap Nilai Perusahaan.

3. Nilai signifikan sebesar $0,003<0,05$. Sehingga dapat disimpulkan bahwa secara parsial Struktur Modal berpengaruh signifikan terhadap Nilai Perusahaan.

4. Nilai signifikan sebesar $0,002<0,05$. Sehingga dapat disimpulkan bahwa secara parsial Leverage berpengaruh signifikan terhadap Nilai Perusahaan.

5. Nilai signifikan sebesar 0,009 $<0,05$. Sehingga dapat disimpulkan bahwa secara parsial Profitabilitas berpengaruh signifikan terhadap Nilai Perusahaan.

6. Nilai signifikan sebesar $0,015<0,05$. Sehingga dapat disimpulkan bahwa secara parsial Ukuran Perusahaan berpengaruh signifikan terhadap Nilai Perusahaan.

\section{Uji Signifikan Simultan (Uji Statistik F)}

Tabel 8

Uji F

\begin{tabular}{|c|l|r|r|r|c|c|}
\hline \multicolumn{2}{|c|}{ Model } & $\begin{array}{c}\text { Sum of } \\
\text { Squares }\end{array}$ & Df & $\begin{array}{c}\text { Mean } \\
\text { Square }\end{array}$ & F & Sig. \\
\hline \multirow{2}{*}{ Regression } & 24.117 & 6 & 4.020 & 6.608 & $.000^{\mathrm{b}}$ \\
\cline { 2 - 8 } & Residual & 94.278 & 155 & 0.608 & & \\
\cline { 2 - 7 } & Total & 118.395 & 161 & & & \\
\hline
\end{tabular}

Struktur Modal, Leverage, Profitabilitas, dan Ukuran Perusahaan secara simultan berpengaruh signifikan terhadap Nilai Perusahaan.

\section{KESIMPULAN}

Hasil penelitian dari pengujian ini menghasilkan bahwa variabel Keputusan investasi (PER), kebijakan dividen (DPR), struktur modal (DER), leverage (DAR), profutabilitas (ROE) dan ukuran perusahaan (Size) secara simultan berpengaruh signifikan terhadap nilai perusahaan perbankan (PBV) yang terdaftar di Bursa Efek Indonesia (BEI) pada periode tahun 2013-2018.

\section{DAFTAR PUSTAKA}

Achmad, Tarmizi, dan Williyanto Kartiko Kusuno. Analisis Rasio-rasio Keuangan Sebagai Indikator dalam Memprediksi Potensi Kebangkrutan Perbankan Indonesia, Media Ekonomi dan Bisnis, 2003, Vol. XV, No. 1.

Ali. Manajemen Risiko - Strategi Perbankan dan Dunia Usaha Menghadapi Tantangan Globlisasi Bisnis. Jakarta: Rajawali Pers, 2006.

Almilia. Analisis Rasio Camel Terhadap Prediksi Kondisi Bermasalah Pada Lembaga Perbankan Periode 2000- 
2002, Jurnal Akuntansi \& Keuangan, 2002, Vol. 7, No. 2, Hal: 131-147.

Andansari, Neni, Kharis Raharjo, Rita Andini. Pengaruh Return on Equity, Price Earning Ratio, Total Asset Turn Over, dan Price Book Terhadap Return Saham. Journal of Accounting, 2016. Vol. 2, No. 2. Anogara, Sinungan. Manajemen Sumber Daya Manusia. Jakarta: Bumi Aksara, 2000.

Arikunto. Metodologi Penelitian Suatu Pendekatan Proposal. Jakarta: PT. Rineka Cipta, 2002.

Bambang Supomo dan Nur Indriantoro. Metodologi Penelitian Bisnis. Cetakan Kedua. Yogyakara: Penerbit BFEE UGM, 2002.

Brigham, E. F., dan J. F. Houston. Manajemen Keuangan. Edisi Bahasa Indonesia. Jakarta: Erlangga, 2010.

Dendawijaya, Lukman. Manajemen Perbankan. Jakarta: Ghalia Indonesia, 2001.

Dendawijaya, Lukman. Manajemen Perbankan. Jakarta: Ghalia Indonesia, 2003.

Fahmi, Irham. Manajemen Investasi. Jakarta: Salemba Empat, 2012.

Guthrie. Human Nutrition. New York: Masby, 1995.

Gujarati. Basic econometrics. Singapore: Mc Graw Hill, Inc, 1995.

Hasibuan, Malayu. Manajemen Sumber Daya Manusia: Pengertian Dasar, Pengertian, dan Masalah. Jakarta: PT. Toko Gunung Agung, 2001.

Helfert, Erich A. Teknik Analisis Keuangan. Jakarta: Erlangga, 1996.

Hempel. Bank Management Text and Cases. Fourth Edition. New York : John Wiley \& Sons, Inc, 1994.

Hermuningsih, Sri. Pengaruh Profitabilitas, Size Terhadap Perusahaan Dengan
Struktur Modal Sebagai Varaibel Intervening. Jurnal Siasat Bisnis, 2018, Vol. 16, No. 02.

Husnan, S. Manajemen Keuangan - Teori dan Penerapan. Buku 2. Yogyakarta: BPFE, 1998.

Kasmir. Manajemen Perbankan. Jakarta: PT. Rajagrafindo Persada, 2004.

Kasmir. Pengantar Manajemen Keuangan. Jakarta: Kencana Prenada Media Group, 2010.

Kuncoro, Mudrajad dan Suhardjono. Manajemen Perbankan. Yogyakarta: BFFE-UGM, 2001.

Kuncoro dan Suhardjono. Manajemen Perbankan - Teori dan Aplikasi. Edisi Pertama. Yogyakarta: Penerbit BPFE, 2002.

Lang, Mark and Russell Lundholm. CrossSectional Determinants of Analyst Ratings of Corporate Disclosures, Journal of Accounting Research, 1993, Vol. 31, No. 2, Hal: 246271.

Mawardi. Analisis Faktor-Faktor Yang Mempengaruhi Kinerja Keuangan Bank Umum Di Indonesia. Jurnal Bisnis Strategi, 2005, Vol. 14, No. 1.

Muljono, T.P. Analisa Laporan Keuangan untuk Perbankan. Edisi revisi 1999. Jakarta, 1999.

Pandia, Frianto. Manajemen Dana dan Kesehatan Bank. Cetakan Pertama. Jakarta: Rineka Cipta, 2012.

Pertiwi, P.J, Tommy, P., Tumiwa, J.RPengaruh Kebijakan Hutang, Keputusan Investasi dan Profitabilitas Terhadap Nilai Perusahaan Food And Beverages yang terdaftar di Bursa Efek Indonesia,Jurnal EMBA, 2016, Vol. 4, No. 01, Hal: 1369-1380.

Rakhimsyah dan Gunawan. 2011. Pengaruh Keputusan Investasi, Keputusan Pendanaan, Kebijakan Deviden 
dan Tingkat Suku Bunga Terhadap Nilai Perusahaan. Jurnal Investasi, 2011, Vol. 7, No. 1, Hal. 31-45.

Rinnaya, Ista Yansi. Pengaruh Profitabilitas, Rasio Aktivitas, Keputusan Pendaan, dan Keputusan Investasi Terhadap Nilai perusahaan. Journal Of Accounting, 2016, Vol. 2, No.2.

Sekaran. Uma. Research Methods for Business. Third Edition. Southern Illionis University, 1992.

Spence. The Quarterly Journal of Economics. Job Market Signaling, 1993, Vol. 87, No. 3, Hal: 355374.

Sugiyono. Metode Penelitian Kuantitatif, Kualitatif, dan $R \& D$. Bandung: Alfabeta, 2017.
Tandelilin, Eduardus. Portofolio dan Investasi Teori dan Aplikasi. Edisi pertama. Yogyakarta: Kanisius, 2010.

Tampubolon, Manahan. Manajemen Keuangan. Medan: Mitra Wacana Media, 2013.

Taswan. Manajemen Perbankan, Konsep, Teknik, dan Aplikasi. Edisi Kedua. Yogyakarta: UPP STIM YKPN, 2010.

Untung Wahyudi dan Hartini Prasetyaning Pawestri. Implikasi Struktur Kepemilikan Terhadap Nilai Perusahaan Dengan Keputusan Keuangan Sebagai Varaibel Intervening Simposium Nasional Akuntansi 9 Padang, 2006. 